\title{
Beszámoló az egészségfejlesztő testmozgással foglalkozó nemzeti kapcsolattartók november 13-14-i, zágrábi üléséről
}

\author{
Report on the focal point meeting of Health-Enhancing Physical Activity, \\ 13-14 November, Zagreb
}

Szerző: Veress Réka $\square$

Emberi Erőforrások Minisztériuma

Beküldve: 2017. 12. 04.

doi: 10.24365/ef.v58i4.216

Kulcsszavak: testmozgás; környezet; HEPA

Keywords: physical activity; environment; HEPA

Az Európai Unió Tanácsának az egészségfejlesztő testmozgás ágazatközi előmozdításáról szóló 2013/C 354/01 ajánlása (2013. november 26.) alapján, 2014 októberében megalakult az egészségfejlesztő testmozgással (Health-Enhancing Physical Activity, HEPA) foglalkozó kapcsolattartók európai uniós hálózata (HEPA focal point network, FP). A hálózat elsődleges feladata, hogy biztosítsa a testmozgásra vonatkozó nemzeti adatok elérhetőségét. A tanácsi ajánlás 23 olyan indikátor tekintetében vár tagállami adatszolgáltatást a nemzeti kapcsolattartók személyén keresztül, amelyek a sport, az egészségügy, az oktatás, a közlekedés, a környezet, a várostervezés, a közbiztonság, a munkahelyi környezet és az időskorúakkal kapcsolatos szakpolitikákat érintik.

Az Egészségügyi Világszervezet (WHO) az Európai Bizottsággal és a HEPA-kapcsolattartókkal együttmúködve, 2015 szeptemberében az egészségfej- lesztő testmozgásra fókuszáló országprofilokat tett közzé, köztük Magyarországra vonatkozóan is.'

2017. november 13-14-én a nemzeti HEPA-kapcsolattartók Zágrábban üléseztek. Az Európai Bizottság és az Egészségügyi Világszervezet (WHO) képviselőinek tájékoztatása alapján 2018-ban megkezdődik a 2015-ben kiadott HEPA-országadatlapok frissítése, a korábban is ismert 23 (finomított) indikátor alapján. A vázolt menetrend a következő:

- December 15-ig a WHO egy belső anyagot készít az adatgyüjtési folyamat minőségének javítása érdekében.

- Január 15-én megjelenik az indikátorokat részletesen bemutató COM Staff Working Document.

- Január 15. és április 27. között zajlik az adatgyűjtés.

- Május közepére elkészülnek az országadatlaptervezetek.

'http://ec.europa.eu/assets/eac/sport/library/factsheets/hungary-factsheet en.pdf (Elérve: 2017. 12. 04.) 
- Május végén a következő FP-találkozó Budapesten lehet.

- Június végéig validálni kell az adatlapokat.

- Szeptember 23-án (az Európai Sporthét EWoS - kezdete) lenne az általános publikáció, az adatlapokat a European Health Information Gateway-re is feltöltik. .i

- 2018. november 9. HEPA FP ülés.

- Lesz néhány tematikus adatlap, amelyek egy kicsit részletesebben mutatják be az egyes ágazatok HEPA-tevékenységét, egy-egy nemzeti jó gyakorlattal.

A találkozón az Európai Bizottság és az Egészségügyi Világszervezet képviselői tájékoztatták a résztvevőket a HEPA területéhez köthető aktuális kezdeményezéseikről:

- 2017 szeptemberében 3 uniós biztos (Navracsics, Andriukaitis, Hogan biztosok) életre hívták Tartuban a Tartu call on healthy lifestyle nevű szakpolitikai kezdeményezést, melyben 15 akciópontot fogalmaznak meg. ${ }^{\text {iii }} \mathrm{Ez}$ a kezdeményezés is megerősíti az ágazatközi HEPA célú fellépés szükségességét.

- A Tartu call folyományaként december 4-5én, Brüsszelben rendeznek egy HEPA-klasztertalálkozót, amelyre mind a nemzeti kapcsolattartókat, mind az Erasmus+ programból támogatott HEPA-projektek képviselőit, továbbá a Sport Tanácsi Munkacsoport képviselőit is meghívták.

- A WHO elindította a korábban NOPA néven ismert online adatbázisát European Health Information Gateway néven, amely a HEPAországadatlapok indikátorait (is) bemutatja európai összesítésben. ${ }^{i v}$

- A találkozó kiemelt témája volt a várostervezés és az aktív közlekedés. Ehhez kapcsolódóan néhány jó gyakorlatot is bemutattak. Az egyik az APEN dán projekt, amelyben városi kieső, főleg ipari régiók idősebb polgárait célozzák, fenntartható testmozgási lehetőségeket kínálva számukra. ${ }^{\vee}$ A másik a SPAcE projekt, amelynek célja az aktív közlekedésben bevált gyakorlatokat szakpolitikai szintekre integrálni. ${ }^{\text {vi }} \mathrm{A}$ WHO és az Európai Bizottság közös, most megjelentett kiadványa, a Towards More Physical Activity in Cities jó áttekintést nyújt erről a területről. vii

További kiemelt téma volt a mozgásgyógyszer, a receptre írható testmozgás. Ehhez kapcsolódóan is mutattak be jó gyakorlatokat:

- Egyesült Királyság: az egészségügyi szakemberek ingyenes, e-learning anyagokhoz férnek hozzá, amelyek a mozgás és az egészség témájáról szólnak. Készültek egyszerúen használható infografikák például a javasolt testmozgásra terhesség idején. ${ }^{\text {viii }}$

- Franciaország: 2016. január 26-tól bekerült az egészségügyi törvény szövegébe, hogy az orvosok mozgást is elöírhatnak a hosszú távú betegségben szenvedő pácienseknek. A mozgás kivitelezésében meghatározott egészségügyi minősítéssel ellátott sportszervezetek vesznek részt.

A HEPA Nemzeti Kapcsolattartók ülését követően november 15-17. között zajlott az éves HEPA Europe konferencia, amelyen szakmai zsüri döntése alapján öt magyar előadó is részt vett.

- Boronyai Zoltán (Magyar Diáksport Szövetség) a SHA P.E. c. Erasmus+ projekt eredményeiről, egy egészségtudatos, jövőorientált életvezetési kulcskompetencia kialakításáról,

- Kälbli Katalin (Magyar Diáksport Szövetség) a NETFIT sajátos nevelési igényű gyermekekre történő adaptációjáról,

- Kaj Mónika (Magyar Diáksport Szövetség) a látássérült gyermekek aerob kapacitásának méréséről,

- Király Anita (Magyar Diáksport Szövetség) a NETFIT értelmi fogyatékos gyermekekre történő adaptációjáról,

\footnotetext{
ii https://gateway.euro.who.int/en/datasets/hepa/(Elérve: 2017. 12. 04.)

iii https://ec.europa.eu/sport/sites/sport/files/ewos-tartu-call en.pdf (Elérve: 2017. 12. 04.)

iv https://gateway.euro.who.int/en/datasets/ (Elérve: 2017. 12. 04.)

${ }^{\vee}$ http://www.apen.dk/om-apen/ (Elérve: 2017. 12. 04.)

vi http://activeenvironments.eu/ (Elérve: 2017. 12. 04.)

vii http://www.euro.who.int/ data/assets/pdf file/0018/353043/2017 WHO Report FINAL WEB.pdf (Elérve: 2017. 12. 04.)

viii https://www.gov.uk/government/publications/start-active-stay-active-infographics-on-physical-activity (Elérve: 2017. 12. 04.)
} 
- Cziráki Péter (Zöldpont) az egészségfejlesztő testmozgást elősegítő eszköztárról, felfogásbeli megközelítésekről beszélt.

A HEPA Europe konferencián kiemelt szimpóziumtéma volt továbbá a Global Observatory for Physical Activity, GoPA. ${ }^{\text {ix }}$ A projekt keretében a testmozgásra vonatkozó országadatlapokat dolgoztak ki, Magyarországról dr. Somhegyi Annamária és Veress Réka kapcsolattartók segítségével. Egyelőre bizonytalan, hogy mikor, de tervben van egy frissített országadatlap készítése. A bemutatott horvát, ír, holland példák alapján általános probléma a WHO által túlbecsült testmozgási mutatók megjelenítése az adatlapokon. (Magyarországon az adatlap alapján 82\%-a teljesíti a felnőtt lakosságnak a WHO által javasolt testmozgási mennyiséget, amely adat más nemzetközi kutatások tükrében túlzó, hazai kutatások hiányában azonban nincs pontosabb adat.)

ix http://www.globalphysicalactivityobservatory.com/ (Elérve: 2017. 12. 04.)

× http://www.globalphysicalactivityobservatory.com/card/?country=HU (Elérve: 2017. 12. 04.) 